\title{
Sewage sludge fertiliser use: Implications for soil and plant copper evolution in forest and agronomic soils
}

\author{
Nuria Ferreiro-Domínguez, Antonio Rigueiro-Rodríguez, M. Rosa Mosquera-Losada* \\ Departamento de Producción Vegetal, Escuela Politécnica Superior de Lugo, Universidad de Santiago de Compostela, Campus Universitario s/n, 27002 Lugo, Spain
}

\section{A R T I C L E I N F O}

\section{Article history:}

Received 26 August 2011

Received in revised form 17 February 2012

Accepted 17 February 2012

Available online 16 March 2012

\section{Keywords:}

Agroforestry

Heavy metals

Leaching

Sowing

Afforestation

Pinus radiata

\begin{abstract}
A B S T R A C T
Fertilisation with sewage sludge may lead to crop toxicity and environmental degradation. This study aims to evaluate the effects of two types of soils (forest and agronomic), two types of vegetation (unsown (coming from soil seed bank) and sown), and two types of fertilisation (sludge fertilisation and mineral fertilisation, with a no fertiliser control) in afforested and treeless swards and in sown and unsown forestlands on the total and available $\mathrm{Cu}$ concentration in soil, the leaching of this element and the Cu levels in plant. The experimental design was completely randomised with nine treatments and three replicates. Fertilisation with sewage sludge increased the concentration of $\mathrm{Cu}$ in soil and plant, but the soil values never exceeded the maximum set by Spanish regulations. Sewage sludge inputs increased both the total and Mehlich $3 \mathrm{Cu}$ concentrations in agronomic soils and the $\mathrm{Cu}$ levels in plant developed in agronomic and forest soils, with this effect pronounced in the unsown swards of forest soils. Therefore, the use of high quality sewage sludge as fertiliser may improve the global productivity of forest, agronomic and silvopastoral systems without creating environmental hazards.
\end{abstract}

(C) 2012 Elsevier B.V. All rights reserved.

\section{Introduction}

There are two different types of soil recent management in Galicia (Spain), ones that could be considered as agronomic because of recent history of liming and fertilisation and forest soil which have not been managed in the recent years. Usually, agronomic soils have higher levels of soil $\mathrm{pH}$ than forest soils and the vegetation in both soils is different depending on the management (Mosquera-Losada et al., 2010a). Land change use is one of the main changes that happened in Galicia (Spain) in the last years due to afforestation promoted by Common Agricultural Policy (CAP) (EU, 2005) through direct payments. Trees were planted in either agronomic or forest soils, depending on the potential growth of trees and soil characteristics that defined site index (Sánchez-Rodríguez et al., 2002). Recently, silvopastoral systems are promoted by the EU (Council Regulation $1698 / 2005 \mathrm{EU}, 2005$ ) as a sustainable method of land management in which trees, animals and pasture are integrated (Mosquera-Losada et al., 2008). Silvopastoral systems can produce social benefits, as the economic return is obtained earlier than when exclusive forest systems are used. As a result, silvopastoral systems tend to enhance the stabilisation of the rural population. Silvopastoral systems also provide environmental benefits such as the improvement of nutrient recycling, the control of soil erosion, a reduction in fire risk and promote biodiversity

\footnotetext{
* Corresponding author.

E-mail address: mrosa.mosquera.losada@usc.es (M.R. Mosquera-Losada).
}

and carbon sequestration (Dupraz and Liagre, 2008; RigueiroRodríguez et al., 2008).

Pinus radiata $\mathrm{D}$. Don is one of the most preferred species of plantation trees in the Atlantic biogeographic region of Europe (mostly in the north of Spain and west of France) due to its rapid growth and the high quality of its logs (Egiarte et al., 2009; Mosquera-Losada et al., 2010a). Moreover, this tree species is also one of the most widely used in the establishment of silvopastoral systems in Australia, New Zealand and Chile (Peri et al., 2007; Benavides et al., 2009).

In Galicia (Spain), pasture production and tree growth can be limited by low soil fertility due to the acidity produced by both the type of parent soil material and by the high annual precipitation (Zas and Alonso, 2002). The use of fertilisers could improve soil fertility as well as tree and pasture productivity (Rigueiro-Rodríguez et al., 2008). One option adopted in many countries around the world is the use of sewage sludge as a fertiliser (EPA, 1994) because of its low cost compared with mineral fertiliser (EFMA, 2009) and because it recycles nutrients (Sigua et al., 2005; Mosquera-Losada et al., $2010 \mathrm{~b}$ ). The productive benefits of the combination of lime and different doses of sewage sludge as a fertiliser in silvopastoral systems established under $P$. radiata D. Don have been shown in Northwest Spain (Mosquera-Losada et al., 2009a, 2010a; Egiarte et al., 2009). However, the application of sewage sludge to soil can pose a threat to the environment, with the major concern arising from the fact that sewage sludge contains a relatively higher concentration of heavy metals than that normally found in soils (Smith, 1996; Singh et al., 2004). Due to potential negative health and environmental effects (Bhogal et al., 2003), the European Directive 86/278 (EU, 1986) and the Spanish Royal Decree 
1310/1990 (BOE, 1990) regulate the use of sewage sludge as soil amendment.

The availability of heavy metals and their transfer to plants, groundwater, animals and, finally, to humans depend on the sewage sludge quality (Katsoyiannis and Samara, 2007), amount of metal in the soil, soil physico-chemical properties (e.g., pH value), the strength of element binding in the soil and the ability of a plant to regulate its uptake (Smith, 1996). In general, Cu tends to be more strongly and effectively sorbed in soil and plants, such as Zn (Kabata-Pendias and Pendias, 2001). However, $\mathrm{Cu}$, because it is one of the most abundant heavy metals in sewage sludge (Ngole, 2007; Mosquera-Losada et al., 2010b), can become toxic when high volumes of sewage sludge are applied (Fjällborg and Dave, 2003). Moreover, $\mathrm{Cu}$ is known to have a number of negative effects both on crops (Baryla et al., 2000) and microorganisms in the soil, which could have a negative effect on soil fertility (Martensson and Torstensson, 1997). Finally, elevated inputs of sewage sludge may also cause an increase in leaching losses of $\mathrm{Cu}$ to ground and surface waters, thus affecting drinking water quality (Karathanasis et al., 2005). Therefore, when sewage sludge is used as fertiliser, it is important to be aware of the effect of this residue on the concentrations of $\mathrm{Cu}$ in the soil and in plant and to assess $\mathrm{Cu}$ leaching risks to groundwater. In previous studies in the same area, the effect of lime and sewage sludge on Cu cycle in plant developed in silvopastoral systems in very acid soils have been previously evaluated (Mosquera-Losada et al., 2009a). However, the effect of sewage sludge applications in different types of soils, previous land use management combined or not with sown sward on Cu cycle has not been yet studied. The aim of this study was to evaluate the total and available $\mathrm{Cu}$ concentration in soil; the leaching of this element to groundwater; and its concentration in plant developed under treatments fertilised with mineral or municipal sewage sludge in simulated pastures (open swards), forest (tree plantation) and silvopastoral systems (tree and pasture sowing) developed under $P$. radiata $\mathrm{D}$. Don that have been established in agronomic and forest soils.

\section{Materials and methods}

\subsection{Characteristics of the study site}

The experiment was initiated in December 2006 through the installation of 27 pots in the town of Piugos (Lugo, Galicia, NW Spain, European Atlantic Biogeographic Region) at an altitude of $470 \mathrm{~m}$ above sea level. Fig. 1 shows the monthly mean precipitation and temperature values for 2007, 2008, and 2009 and the normal mean precipitation and temperature values of the study area. The total annual rainfall was 658.1, 1000, and $872.7 \mathrm{~mm}$ in 2007, 2008,

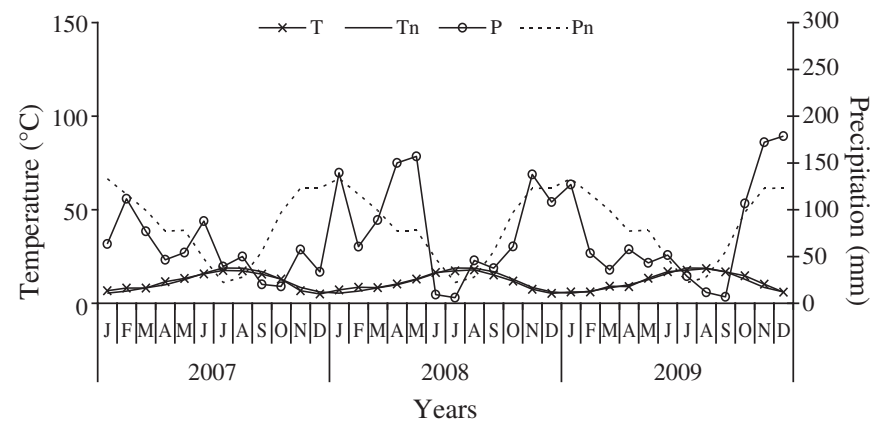

Fig. 1. Mean monthly precipitation and mean monthly temperature in 2007,2008 , and 2009 and mean normal data for the study area. T: mean monthly temperature $\left({ }^{\circ} \mathrm{C}\right), \mathrm{Tn}$ : mean normal temperature, $\mathrm{P}$ : mean monthly precipitation $(\mathrm{mm})$, and $\mathrm{Pn}$ : mean normal precipitation. and 2009, respectively. The rainfall registered in the spring of 2007, 2008, and 2009 was 439.8, 604.5, and $368.4 \mathrm{~mm}$, respectively. In general, those years were drier than the mean normal year ( $998.3 \mathrm{~mm}$ ) for the study area. However, the mean monthly precipitation in 2007 was higher than the mean normal precipitation from June to August, which reduced the drought period when compared with the years 2008 and 2009, in which pasture growth was limited by a lack of rainfall. The annual mean temperature was mild $\left(12^{\circ} \mathrm{C}\right)$.

The pots used in this experiment were cylindrical (approximately $2 \mathrm{~m}^{3}$ in size with a height of $144 \mathrm{~cm}$ and width of $134.5 \mathrm{~cm}$ ) and were filled with soils. Fifteen pots were filled with agronomic soil from Sarria (Lugo, Galicia, NW Spain) and the others with forest soil (12 pots) from Bascuas (Condesmo, Lugo, Galicia, NW Spain). The soils were Gleyic Umbrisols (FAO classification) and Umbrept Inceptisols (USDA system). Agronomic soil was previously used for grass and forage crops and forest soil for production of pine wood. In each pot, a lysimeter was installed at a depth of $135 \mathrm{~cm}$ to study the leaching of nutrients. The lysimeter was composed of a PVC pipe of $2 \mathrm{~cm}$ of diameter introduced after making holes in the pots. The tube was fitted precisely to the pot so that no water was leached outside, with the exception of the hole in this PVC pipe.

Initial agronomic soil analyses showed a loamy sand soil texture ( $83.51 \%$ sand, $12.33 \%$ silt and $4.15 \%$ clay) with a highly acid $\mathrm{KCl} \mathrm{pH}$ (4.46) (Faithfull, 2002). Meanwhile, the forest soil analyses had a sandy loam soil texture ( $71.69 \%$ sand, $19.46 \%$ silt and $8.85 \%$ clay) and a highly acid $\mathrm{KCl} \mathrm{pH}$ (4.27) (Faithfull, 2002), as in agronomic soils. The main difference between both soils was the higher concentration of $\mathrm{Al}$ in forest soil $\left(0.74 \mathrm{cmol}(+) \mathrm{kg}^{-1}\right)$ than in agronomic soil $\left(0.55 \mathrm{cmol}(+) \mathrm{kg}^{-1}\right)$. All heavy metal concentrations in both agronomic and forest soils (Table 1) were below the maximum thresholds for the use of sewage sludge as fertiliser as specified by the EU Directive 86/278/CEE (EU, 1986) and Spanish legislation under R.D. 1310/1990 (BOE, 1990).

\subsection{Experimental design}

The experimental design was completely randomised with nine treatments and three replicates. Treatments followed a design that consisted of a fractional factorial design of a $2 p$ fully factorial, with $" p "=4$ factors ( 2 levels per factor). Treatments were chosen because they are the most traditional practices in the area of study (agronomic soil without tree, forest soil without pasture, and silvopastoral systems) in forest and agronomic lands. The treatments consisted of the following: (1) Agronomic soil + pasture sowing (Agronomic $+\mathrm{P}$ ); (2) Agronomic soil + pasture sowing + sewage sludge (Agronomic + PS); (3) Agronomic soil + pasture sowing + mineral (Agronomic + PM); (4) Agronomic soil + pasture sowing + sewage sludge + tree (Agronomic + PST); (5) Agronomic soil + pasture sowing + mineral + tree (Agronomic + PMT); (6) Forest soil + sewage sludge + tree $($ Forest + ST) $;(7)$ Forest soil + mineral + tree $($ Forest + MT) $;(8)$ Forest soil + pasture sowing + sewage sludge + tree $($ Forest + PST $)$; and

Table 1

Heavy metal concentrations in the agronomic soil and in the forest soil at the beginning of the experiment and legal limits established by European Directive 86/278 and Spain R.D. 1310/1990. Limits depend on soil $\mathrm{pH}$ (minimum: soil $\mathrm{pH}<7$, maximum: soil $\mathrm{pH}>7$ ). - : element concentration below detection limit of the technique used in its determination.

\begin{tabular}{lllllll}
\hline \multicolumn{7}{l}{ Heavy metal concentrations $\left(\mathrm{mg} \mathrm{kg}^{-1}\right)$} \\
Soil & $\mathrm{Cd}$ & $\mathrm{Cu}$ & $\mathrm{Cr}$ & $\mathrm{Ni}$ & $\mathrm{Pb}$ & $\mathrm{Zn}$ \\
\hline Initial agronomic soil & 0.1 & 1 & 0.9 & - & 17.7 & 28.8 \\
Initial forest soil & 0.9 & 7.8 & 2 & - & - & 32.5 \\
Spanish law limits & $1-3$ & $50-210$ & $100-150$ & $30-112$ & $50-300$ & $150-450$ \\
\hline
\end{tabular}


(9) Forest soil + pasture sowing + mineral + tree (Forest + PMT). The following physical parameters were used:

- Pasture sowing (P): the sward was sown with a mixture of Dactylis glomerata L. var. Artabro (12.5 $\left.\mathrm{kg} \mathrm{ha}^{-1}\right)$, Lolium perenne L. var. Brigantia (12.5 $\mathrm{kg} \mathrm{ha}^{-1}$ ) and Trifolium repens L. var. Huia (4 $\left.\mathrm{kg} \mathrm{ha}^{-1}\right)$ in December 2006.

- Tree (T): a one-year-old $P$. radiata D. Don tree was planted in January 2007.

- Sewage sludge (S): an anaerobically digested sludge with an input of $320 \mathrm{~kg}$ total $\mathrm{Nha}^{-1}$ was applied in December 2006, which means around $80 \mathrm{~kg}$ of available $\mathrm{N}$ per hectare if a $25 \%$ of mineralization rate is considered (EPA, 1994).

- Mineral (M): in the Agronomic + PM, Agronomic + PMT, Forest + MT, and Forest + PMT treatments, $500 \mathrm{~kg} \mathrm{ha}^{-1}$ of $8(\% \mathrm{~N}): 24(\%$ $\left.\mathrm{P}_{2} \mathrm{O}_{5}\right): 16\left(\% \mathrm{~K}_{2} \mathrm{O}\right)$ was applied at the beginning of the years 2007 , 2008 , and 2009 , and $40 \mathrm{~kg}$ of $\mathrm{N} \mathrm{ha}^{-1}$ as calcium ammonium nitrate $(26 \% \mathrm{~N})$ was applied after each harvest, which is traditionally used in the area.

\subsection{Sewage sludge}

Anaerobically digested sludge was taken from the municipal waste treatment plant of Lugo. The required amount of sewage sludge was calculated according to total $\mathrm{N}$ and dry matter content (EPA, 1994), taking into account that approximately $25 \%$ of the total $N$ from anaerobically digested sewage sludge is available in the first year after application as indicates EPA (1994). EU Directive 86/278/ CEE (EU, 1986) and Spanish regulation R.D. 1310/1990 (BOE, 1990) regarding heavy metal concentrations in the application of sewage sludge to soil were also considered. The composition of the sewage sludge that was applied is summarised in Table 2.

\subsection{Field sampling and laboratory determinations}

Soil samples were collected at a depth of $25 \mathrm{~cm}$, as described in R.D. 1310/1990 (BOE, 1990) in March 2008, January 2009 and January 2010. In the laboratory, soil samples were air-dried, passed through a $2 \mathrm{~mm}$ sieve, and ground with an agate mortar. Soil $\mathrm{pH}$ was determined in $\mathrm{KCl}$ (1:2.5) (Faithfull, 2002), and the total Cu concentration was analysed with the VARIAN 220FS spectrophotometer using atomic absorption (VARIAN, 1989) after a nitric acid digestion made in a CEM MDS-2000 microwave (CEM, 1994). Available Cu was measured after

Table 2

Chemical properties of the sewage sludge applied and legal limits established by European Directive 86/278 and Spain R.D. 1310/1990. Limits depend on soil pH (minimum: soil $\mathrm{pH}<7$, maximum: soil $\mathrm{pH}>7$ ).

\begin{tabular}{lll}
\hline Values & & \\
\hline Parameters & Anaerobic sludge & Spanish law limits \\
\hline Dry matter, \% & 20.47 & \\
$\mathrm{pH}$ & 7.47 & \\
$\mathrm{~N}, \mathrm{~g} \mathrm{~kg}^{-1}$ & 35 & \\
$\mathrm{P}, \mathrm{g} \mathrm{kg}^{-1}$ & 17.8 & \\
$\mathrm{~K}, \mathrm{~g} \mathrm{~kg}^{-1}$ & 3.5 & \\
$\mathrm{Ca}, \mathrm{g} \mathrm{kg}^{-1}$ & 27.1 & \\
$\mathrm{Mg}, \mathrm{g} \mathrm{kg}^{-1}$ & 8.4 & $1000-1500$ \\
$\mathrm{Na}, \mathrm{g} \mathrm{kg}^{-1}$ & 1.5 & $1000-1750$ \\
$\mathrm{Fe}, \mathrm{g} \mathrm{kg}^{-1}$ & 17.9 & $300-400$ \\
$\mathrm{Cr}, \mathrm{mg} \mathrm{kg}^{-1}$ & 39.4 & $2500-4000$ \\
$\mathrm{Cu}, \mathrm{mg} \mathrm{kg}^{-1}$ & 142.7 & $20-40$ \\
$\mathrm{Ni}, \mathrm{mg} \mathrm{kg}^{-1}$ & 29.4 & $750-1200$ \\
$\mathrm{Zn}, \mathrm{mg} \mathrm{kg}^{-1}$ & 1248.56 & \\
$\mathrm{Cd}, \mathrm{mg} \mathrm{kg}^{-1}$ & 0.7 & \\
$\mathrm{~Pb}, \mathrm{mg} \mathrm{kg}^{-1}$ & 84.4 & \\
$\mathrm{Mn}, \mathrm{mg} \mathrm{kg}^{-1}$ & 6.1 & \\
\hline
\end{tabular}

extraction with Mehlich 3 (Mehlich, 1985) with a VARIAN 220FS spectrophotometer, using atomic absorption (VARIAN, 1989).

The water from the lysimeters was extracted each week, unless drought caused a lack of water, and measured with a volumetric ware. The concentration of $\mathrm{Cu}$ leaching into the water was determined with the VARIAN 220FS spectrophotometer using atomic absorption (VARIAN, 1989). Total Cu leached was estimated by multiplying $\mathrm{Cu}$ concentration and the water leached in each sampling. Copper leached for a period in each sampling was summed to obtain the global period $\mathrm{Cu}$ leached. The weighted mean of the $\mathrm{Cu}$ concentration in the leached water was calculated as:

$\bar{x}=\frac{\sum_{i=1}^{n} x_{i} w_{i}}{\sum_{i=1}^{n} w_{i}}=\frac{x_{1} w_{1}+x_{2} w+x_{3} w_{3}+\ldots+x_{n} w_{n}}{w_{1}+w_{2}+w_{3}+\ldots+w_{n}}$

Where $\mathrm{x}_{\mathrm{i}}$ is the concentration of $\mathrm{Cu}$ in the water leached, and $\mathrm{w}_{\mathrm{i}}$ is the volume of water leached.

To estimate $\mathrm{Cu}$ content in plant, two samples of pasture were randomly taken with an electric hand clipper at a height of $2.5 \mathrm{~cm}$ per pot $\left(0.3 \times 0.3 \mathrm{~m}^{2}\right)$ in May, June, and August 2007; in May and July 2008; and in May and June 2009 (autumn data were not used in this study). Later, the samples were labelled and transported to the laboratory, where the samples were dried at $60{ }^{\circ} \mathrm{C}$ for $72 \mathrm{~h}$, after which they were ground and chemically analysed. The $\mathrm{Cu}$ content in plant was determined with the VARIAN 220FS spectrophotometer using atomic absorption (VARIAN, 1989) after a nitric acid digestion was made in a CEM MDS-2000 microwave (CEM, 1994).

\subsection{Statistical analysis}

Soil variables and total $\mathrm{Cu}$ leached were analysed with repeated measures ANOVA (proc glm procedure) following the model $Y_{i j k}=$ $\mu+A_{i}+T_{j}+T_{j i}+\varepsilon_{i j k}$, within Pasture + Tree treatment (Agronomic + PMT, Agronomic + PST, Forest + PMT and Forest + PST treatments), forest soil treatments (Forest + PMT, Forest + PST, Forest + ST and Forest MT treatments), agronomic soil treatments (Agronomic + PMT, Agronomic + PST, Agronomic + PM and Agronomic + PS treatments) and agronomic treatments only with pasture (treatments Agronomic + P, Agronomic + PM and Agronomic + PS treatments). In the repeated measures ANOVA, the variables were represented as follows: $Y_{i j k}$ is the studied variable, $\mu$ is the variable mean, $A_{i}$ is the year $i, T_{j}$ indicates treatment $\mathrm{j}, \mathrm{TA}_{\mathrm{ji}}$ is the treatment year interaction and $\varepsilon_{\mathrm{ijk}}$ is the error.

The $\mathrm{Cu}$ data from the soil, leached water and pasture variables were also analysed with three two-way ANOVAs (proc glm procedure) following the model $\mathrm{Y}_{\mathrm{ij}}=\mu+\mathrm{F}_{\mathrm{i}}+\mathrm{T}_{\mathrm{j}}+\varepsilon_{\mathrm{ij}}$. The first ANOVA was performed to discern the effects of soil type ( $\mathrm{T}$ : forest and agronomic) with two levels of fertilisation (F: sludge and mineral) and their interactions (soil $\times$ fertilisation) in silvopastoral systems (Pasture + Tree) $($ Agronomic + PMT, Agronomic + PST, Forest + PMT and Forest + PST treatments). $Y_{i j}$ is the studied variable; $\mu$ is the variable mean; $F_{i}$ is the fertiliser factor $\mathrm{i}$; $\mathrm{T}_{\mathrm{j}}$ is the soil type factor $\mathrm{j}$; and $\varepsilon_{\mathrm{ij}}$ is the error. The second 2-way ANOVA was performed to discern the effects of two levels of pasture vegetation (S: sown and unsown pasture) with two levels of fertilisation (F: sludge and mineral) and their interactions (sown $\times$ fertilisation) on forest soil (Forest + PMT, Forest + PST, Forest + ST and Forest MT treatments). $Y_{i j}$ is the studied variable; $\mu$ is the variable mean; $F_{i}$ is the fertiliser factor $\mathrm{i} ; \mathrm{T}_{\mathrm{j}}$ is the vegetation factor $\mathrm{j}$; and $\varepsilon_{\mathrm{ij}}$ is the error. The third 2-way ANOVA was performed to discern the effects of two levels of tree plantation (T: tree and no tree plantation) with two levels of fertilisation (F: sludge and mineral) and their interactions $($ silvo $\times$ fertilisation) on agronomic soil (Agronomic + PMT, Agronomic + PST, Agronomic + PM and Agronomic PS treatments). $Y_{i j}$ is the studied variable; $\mu$ is the variable mean; $F_{i}$ is the fertiliser factor $i$; $T_{j}$ is the vegetation factor $\mathrm{j}$; and $\varepsilon_{\mathrm{ij}}$ is the error. Finally, a 1-way ANOVA of one factor with three levels of fertilisation $F$ (no fertilisation [NF], mineral $[\mathrm{M}]$ and sludge $[\mathrm{S}]$ ) was performed to discern the effects of 
fertilisation on agronomic soil with herbaceous vegetation (Agronomic $+\mathrm{P}$, Agronomic + PM and Agronomic + PS treatments).

The LSD test was used for subsequent pair wise comparisons $(p<0.05 ; a=0.05)$ if the ANOVA was significant. The statistical software package SAS (2001) was used for all analyses.

\section{Results}

\subsection{Soil}

\subsection{1. $\mathrm{KCl}$ soil $\mathrm{pH}$}

Table 3 shows that the $\mathrm{KCl}$ soil $\mathrm{pH}$ was lower in 2010 than in 2008 in Pasture + Tree treatments and when forest and agronomic soils were separately taken into account. However, when evaluating only the effect of the fertilisation treatments on the treeless agronomic soil (Agronomic soils: Pasture), the $\mathrm{KCl}$ soil $\mathrm{pH}$ was similar at the end of the experiment (2010) to that at the beginning (2008). In Pasture + Tree treatments (Fig. 2), the soil pH was significantly affected by the type of soil $(p<0.001)$ in 2008 (agronomic: 4.91 vs. forest: 4.44), 2009 ( $\mathrm{p}<0.001$ ) (agronomic: 4.77 vs. forest: 4.32) and 2010 (agronomic: 4.73 vs. forest: 4.25$)$ and by the type of fertilisation $(\mathrm{p}<0.05)$ (sludge: 4.55 vs. mineral: 4.43 ) in 2010. Moreover, in the agronomic soils, the soil $\mathrm{pH}$ was significantly higher $(\mathrm{p}<0.001)$ when sewage sludge was applied (PST) compared with mineral fertilisation (PMT) in 2010. In 2009, within the Forest soils (Fig. 2), the $\mathrm{KCl}$ soil pH was significantly higher $(p<0.01)$ when the soil was fertilised with sludge rather than with mineral fertiliser (sludge: 4.38 vs. mineral: 4.31). No differences in the $\mathrm{KCl}$ soil $\mathrm{pH}$ appeared between treatments when treeless Agronomic soils were taken into account ( $p>0.05)$.

\subsubsection{Total copper}

The total soil Cu was lower in 2009 and 2010 compared with 2008 in Pasture + Tree treatments and in the treatments established in the forest soils, while at the same time in agronomic soils differences were not observed between years (Table 3). In Pasture + Tree treatments (Fig. 3), the total soil levels of $\mathrm{Cu}$ were significantly affected by the type of soil $(\mathrm{p}<0.001)$ in 2008 (agronomic: $12.07 \mathrm{mg}$ total $\mathrm{Cu}$ $\mathrm{kg}^{-1}$ vs. forest: $4.97 \mathrm{mg}$ total $\mathrm{Cu} \mathrm{kg} \mathrm{kg}^{-1}$ ), 2009 (agronomic: $11.22 \mathrm{mg}$ total $\mathrm{Cu} \mathrm{kg}{ }^{-1}$ vs. forest: $2.47 \mathrm{mg}$ total $\mathrm{Cu} \mathrm{kg}^{-1}$ ) and 2010 (agronomic: $11.02 \mathrm{mg}$ total $\mathrm{Cu} \mathrm{kg} \mathrm{kg}^{-1}$ vs. forest: $1.25 \mathrm{mg}$ total $\left.\mathrm{Cu} \mathrm{kg}^{-1}\right)$. On the other hand, in 2010, in the agronomic soils (Fig. 3), the interaction of silvo $\times$ fertilisation was significant $(p<0.05)$, with the concentration of total soil Cu higher in the treeless soils fertilised with sludge (PS) than those with mineral fertiliser (PM). Moreover, in the treeless agronomic soils in which only the effect of the fertilisation treatments was studied

\section{Table 3}

Water soil $\mathrm{pH}$, total $\mathrm{Cu}\left(\mathrm{mg} \mathrm{kg}^{-1}\right)$ and amount of $\mathrm{Cu}$ extracted with Mehlich 3 $\left(\mathrm{mg} \mathrm{kg}^{-1}\right)$ in Pasture + Tree treatments, in forest soils, in agronomic soils and in no forested agronomic soils in 2008, 2009 and 2010. Different letters indicate significant differences between years. ns: not-significant, ${ }^{* * *}: \mathrm{p}<0.001{ }^{* *}: \mathrm{p}<0.01$, SEM: mean standard error.

\begin{tabular}{|c|c|c|c|c|c|c|}
\hline & \multirow[b]{2}{*}{ Parameter } & \multicolumn{3}{|l|}{ Year } & \multirow[b]{2}{*}{$\begin{array}{l}\text { Year } \\
\text { effect }\end{array}$} & \multirow[b]{2}{*}{ SEM } \\
\hline & & 2008 & 2009 & 2010 & & \\
\hline \multirow[t]{3}{*}{ Pasture + Tree } & $\mathrm{KCl} \mathrm{pH}$ & $4.68 \mathrm{a}$ & $4.55 \mathrm{~b}$ & $4.49 \mathrm{~b}$ & $* * *$ & 0.04 \\
\hline & Total $\mathrm{Cu}\left(\mathrm{mg} \mathrm{kg}^{-1}\right)$ & $8.52 \mathrm{a}$ & $6.84 \mathrm{~b}$ & $6.13 \mathrm{~b}$ & $* *$ & 0.79 \\
\hline & Cu Mehlich $3\left(\mathrm{mg} \mathrm{kg}^{-1}\right)$ & 0.57 & 0.69 & 0.71 & ns & 0.07 \\
\hline \multirow[t]{3}{*}{ Forest soils } & $\mathrm{KCl} \mathrm{pH}$ & $4.45 \mathrm{a}$ & $4.35 \mathrm{~b}$ & $4.27 \mathrm{c}$ & $* * *$ & 0.02 \\
\hline & Total $\mathrm{Cu}\left(\mathrm{mg} \mathrm{kg}^{-1}\right)$ & $5.17 \mathrm{a}$ & $2.56 \mathrm{~b}$ & $1.90 \mathrm{~b}$ & $* * *$ & 0.35 \\
\hline & Cu Mehlich $3\left(\mathrm{mg} \mathrm{kg}^{-1}\right)$ & 0.23 & 0.32 & 0.17 & ns & 0.04 \\
\hline \multirow[t]{3}{*}{ Agronomic soils } & $\mathrm{KCl} \mathrm{pH}$ & $4.89 \mathrm{a}$ & $4.72 \mathrm{~b}$ & $4.78 \mathrm{~b}$ & $* *$ & 0.02 \\
\hline & Total $\mathrm{Cu}\left(\mathrm{mg} \mathrm{kg}^{-1}\right)$ & 12.19 & 10.98 & 11.58 & ns & 0.35 \\
\hline & Cu Mehlich $3\left(\mathrm{mg} \mathrm{kg}^{-1}\right)$ & 0.96 & 1.09 & 1.14 & ns & 0.06 \\
\hline \multirow{3}{*}{$\begin{array}{l}\text { Agronomic soils: } \\
\text { pasture }\end{array}$} & $\mathrm{KCl} \mathrm{pH}$ & $4.87 \mathrm{a}$ & $4.70 \mathrm{~b}$ & $4.94 \mathrm{a}$ & $* * *$ & 0.04 \\
\hline & Total $\mathrm{Cu}\left(\mathrm{mg} \mathrm{kg}^{-1}\right)$ & 12.78 & 10.74 & 11.78 & ns & 0.43 \\
\hline & Cu Mehlich $3\left(\mathrm{mg} \mathrm{kg}^{-1}\right)$ & 0.99 & 1.29 & 1.19 & ns & 0.07 \\
\hline
\end{tabular}

(Agronomic soils: Pasture), it was observed again that the application of sewage sludge increased the concentration of total soil $\mathrm{Cu}$ more than fertilisation with mineral fertiliser in both 2009 and 2010 $(\mathrm{p}<0.05)$. No differences in the amount of total soil $\mathrm{Cu}$ appeared between treatments when forest soils were taken into account $(\mathrm{p}>0.05)$.

\subsubsection{Copper Mehlich 3}

The amount of $\mathrm{Cu}$ extracted with Mehlich 3 in 2008, 2009 and 2010 did not change over the period of the study (Table 3). Fig. 4 shows the amount of $\mathrm{Cu}$ extracted with Mehlich 3 in Pasture + Tree treatments and agronomic soils in 2008, 2009 and 2010. In forest soils, there were no significant differences between treatments $(p>0.05)$. The three year mean concentration of $\mathrm{Cu}$ extracted with Mehlich 3 was significantly higher in agronomic soils than in forest soils $(\mathrm{p}<0.05)$ (agronomic: $0.94 \mathrm{mg}$ Mehlich $\mathrm{Cu} \mathrm{kg}{ }^{-1}$ vs. forest: $0.27 \mathrm{mg}$ Mehlich $\mathrm{Cu} \mathrm{kg}^{-1}$ ). In agronomic soils, the amount of $\mathrm{Cu}$ extracted with Mehlich 3 was significantly affected by the treatments in 2010 (silvo $\times$ fertilisation interaction effect: $\mathrm{p}<0.05$ ) and revealed that the available soil $\mathrm{Cu}$ was higher in the soils without trees that were fertilised with sludge (PS) than those with mineral fertiliser (PM) and in soils afforested with $P$. radiata $D$. Don to which sewage sludge was applied (PST). Moreover, in treeless agronomic soils, it was also observed that fertilisation with sludge (S) more significantly increased the amount of $\mathrm{Cu}$ extracted with Mehlich 3 than it did in the unfertilised treatment (NF) in $2008(\mathrm{p}<0.05)$.

\subsubsection{Copper in leaching water}

The significant effect of the study years on total $\mathrm{Cu}$ leached in Pasture + Tree treatments $(\mathrm{p}<0.001)$ and in agronomic and forest soils $(\mathrm{p}<0.05)$ are shown in Fig. 5. In all treatments, total $\mathrm{Cu}$ leached was lower at the end of the experiment (2009) than in the previous year (2008). However, total Cu leached was not significantly modified by the treatments applied ( $p>0.05$ ) (data not shown). On the other hand, in treeless agronomic soils (Agronomic soils: Pasture), it was observed that the weighted mean of the $\mathrm{Cu}$ concentration in the leached water was significantly higher $(\mathrm{p}<0.05)$ in the no fertilisation treatment (NF) than in the treatments in which mineral fertiliser $(\mathrm{M})$ and sewage sludge (S) were applied (NF: $0.0087^{\mathrm{a}}$; M: $0.0057^{\mathrm{b}}$ and S:

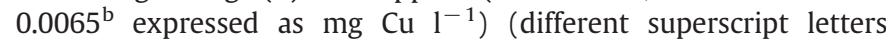
indicate significant differences between treatments). In Pasture + Tree, in both agronomic soils with trees and in forest soils, there were no significant differences between treatments ( $p>0.05)$.

\subsection{Concentrations of $\mathrm{Cu}$ in plant}

Fig. 6 presents the concentrations of $\mathrm{Cu}$ in plant in the harvests of spring in which differences between treatments were observed. When the effect of the type of soil and the type of fertilisation were evaluated (Pasture + Tree treatments), the concentration of $\mathrm{Cu}$ in plant was significantly higher in agronomic than in forest soils in May (soil effect: $\mathrm{p}<0.001$; agronomic: $6.97 \mathrm{mg} \mathrm{Cu} \mathrm{kg}{ }^{-1}$ vs. forest: $3.68 \mathrm{mg} \mathrm{Cu} \mathrm{kg}^{-1}$ ) and August 2007 (soil effect: $\mathrm{p}<0.05$; agronomic: $5.86 \mathrm{mg} \mathrm{Cu} \mathrm{kg}^{-1}$ vs. forest: $\left.4.08 \mathrm{mg} \mathrm{Cu} \mathrm{kg}^{-1}\right)$ and when soils were fertilised with sludge rather than with mineral fertiliser in May 2007 (fertilisation effect: $\mathrm{p}<0.05$; sludge: $5.90 \mathrm{mg} \mathrm{Cu} \mathrm{kg}^{-1}$ vs. mineral: $4.75 \mathrm{mg} \mathrm{Cu} \mathrm{kg}^{-1}$ ). In May 2009, the interaction of soil $\times$ fertilisation and the effect of the type of soil were significant $(p<0.05$ ), with the concentrations of $\mathrm{Cu}$ in plant lower in the forest soils fertilised with minerals (MT) than in the other treatments established in forest (ST) and agronomic soils (MT and ST). Lower amounts of $\mathrm{Cu}$ in plant of the pots with forest soil and fertilised with minerals (MT) than in the other pots was also observed in the harvest of May $2007(\mathrm{p}<0.001)$. Moreover, in August 2007, the application of mineral fertiliser to the forest soils (MT) again significantly decreased $(\mathrm{p}<0.05)$ the 


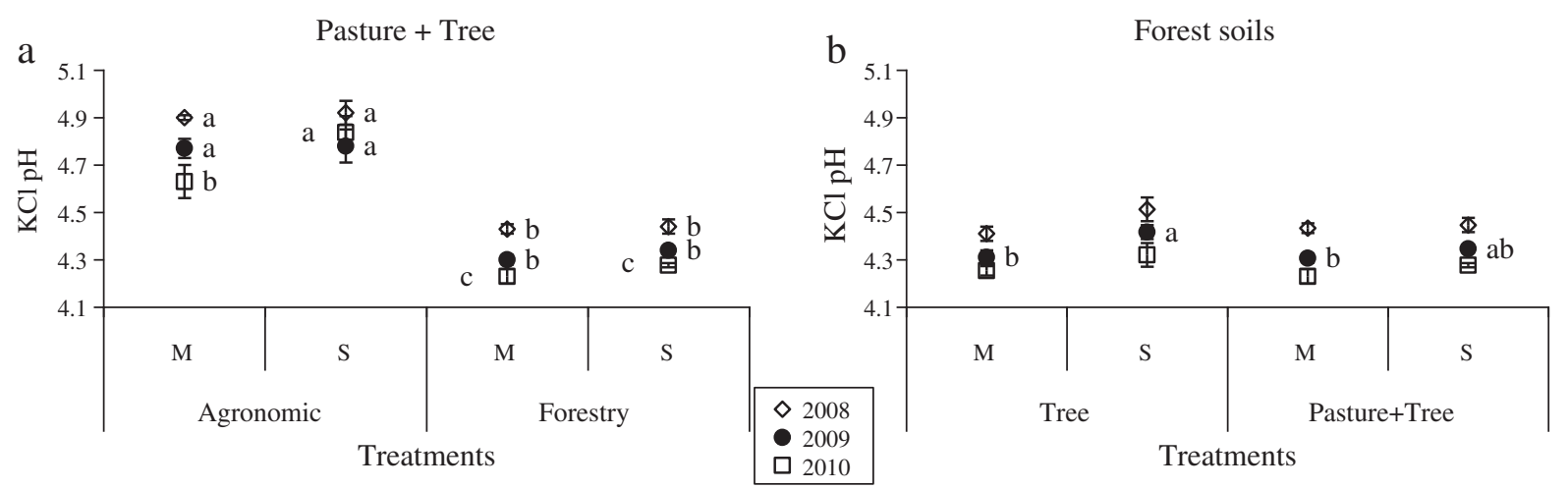

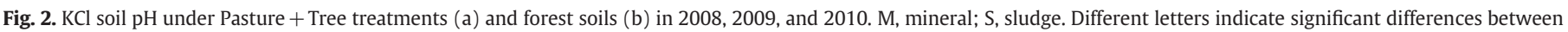
treatments within Pasture + Tree treatments (a) and forest soils (b) within the same year. Vertical lines indicate mean standard error.

concentration of $\mathrm{Cu}$ in plant in this case when compared with the mineral fertilisation of the pots filled with agronomic soil.

Within the forest soils, the concentration of $\mathrm{Cu}$ in plant was significantly higher when the soils were fertilised with sludge rather than with mineral fertiliser and in the unsown pots compared with the sown pots in May 2007 (fertilisation effect: $p<0.05$; sludge: $5.62 \mathrm{mg}$ $\mathrm{Cu} \mathrm{kg}{ }^{-1}$ vs. mineral: $3.65 \mathrm{mg} \mathrm{Cu} \mathrm{kg}{ }^{-1}$ ) (sown effect: $\mathrm{p}<0.05$; unsown: $5.58 \mathrm{mg} \mathrm{Cu} \mathrm{kg}^{-1}$ vs. sown: $3.68 \mathrm{mg} \mathrm{Cu} \mathrm{kg}^{-1}$ ). In May 2007, it was also observed that the concentration of $\mathrm{Cu}$ in plant was significantly higher $(p<0.05)$ in the pots without pasture sowing and fertilised with sewage sludge (ST) than in the other treatments established (MT, PMT and PST).

In the agronomic soils, in May 2009, the interaction of silvo $\times$ fertilisation was significant $(\mathrm{p}<0.05)$, with the levels of $\mathrm{Cu}$ in plant higher in the pots without trees and fertilised with sludge (PS) than in the pots without trees but fertilised with minerals
(PM) and in the pots planted with trees and fertilised with sludge (PST).

Finally, as observed in Fig. 7 the amount of $\mathrm{Cu}$ extracted by the pasture was higher when the availability of $\mathrm{Cu}$ increased.

\section{Discussion}

In this experiment, the soil pH in 2010 was lower than in 2008. Firstly, $\mathrm{pH}$ is usually reduced by $\mathrm{N}$ mineralisation as the step from $\mathrm{NH}_{4}^{+}$to $\mathrm{NO}_{3}^{-}$occurs (releasing $\mathrm{H}^{+}$into the soil solution Whitehead, 1995) and, secondly, because tree and pasture extract cations from the soil releasing $\mathrm{H}^{+}$(Nillsson, 2004; Mosquera-Losada et al., 2006). The reduction of the soil $\mathrm{pH}$ possibly restricted the soil's biological activity (Omil et al., 2007; Djukic et al., 2009) and therefore the incorporation and mineralisation of sewage sludge was low, which may have produced a reduction of the total soil $\mathrm{Cu}$ over time in
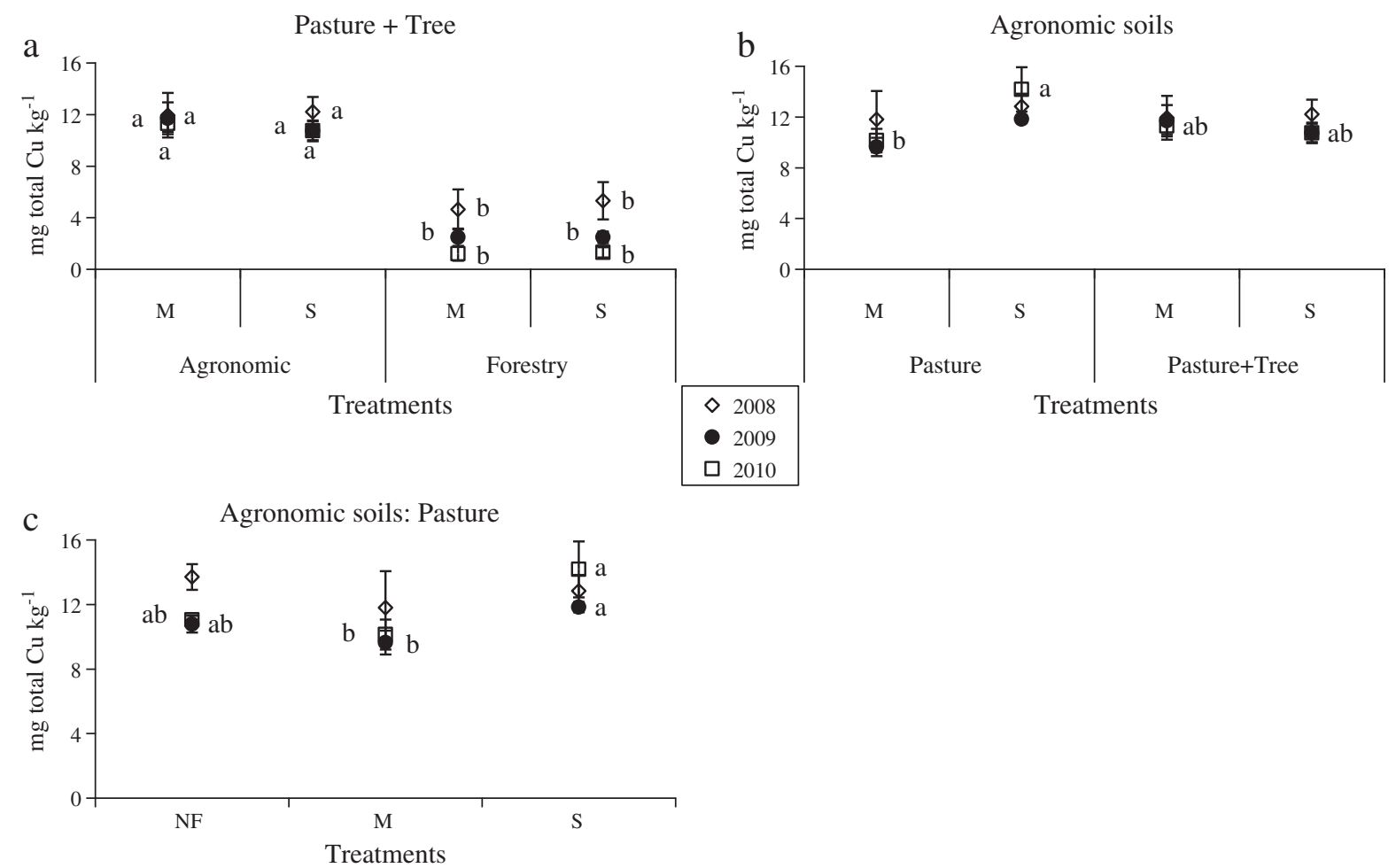

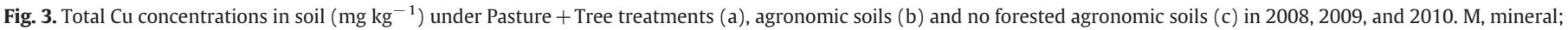

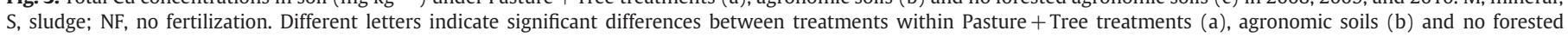
agronomic soils (c) within the same year. Vertical lines indicate mean standard error. 

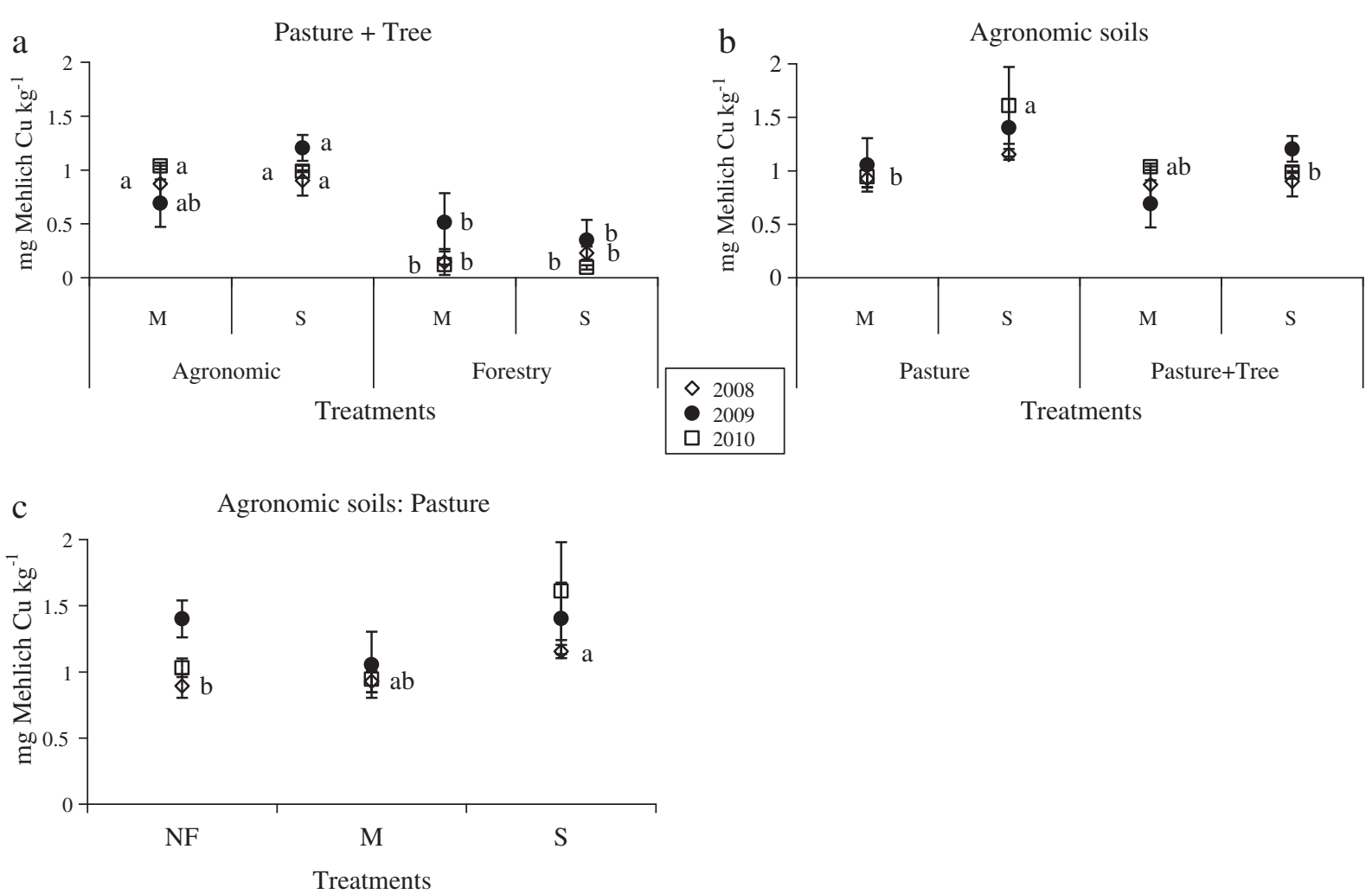

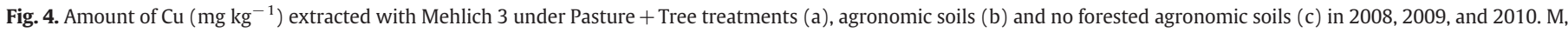

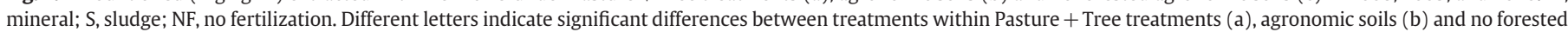
agronomic soils (c) within the same year. Vertical lines indicate mean standard error.

Pasture + Tree treatments and in forest soils because the Cu extracted by plants was higher than that incorporated into the soil. Moreover, Cu solubility is negatively affected by high levels of organic matter. In the present experiment, the levels of organic matter were so high that could have favoured the $\mathrm{Cu}$ complex formation and therefore reduce the $\mathrm{Cu}$ solubility from the start to the end of the study. The lower total soil $\mathrm{Cu}$ in 2010 than in 2008 might also be explained by the leaching of this element through the soil profile (especially at the beginning of the study). In this experiment, the proportion of sand in agronomic (83.51\%) and in forest soils (71.69\%) was high in comparison with the percentage of clay and may have favoured $\mathrm{Cu}$ leaching (Zubillaga et al., 2008; Smith, 2009). Depletion of soil $\mathrm{Cu}$ concentration over time in sandy soils was previously documented by Rigueiro-Rodríguez et al. (2010) in a silvopastoral established

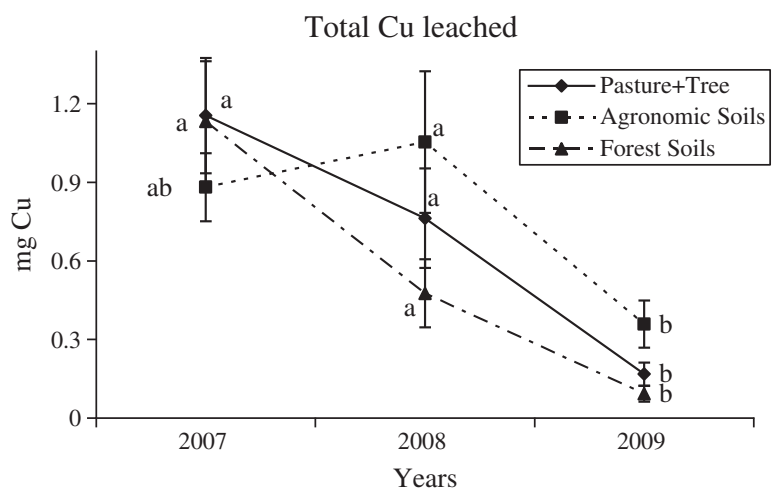

Fig. 5. Total copper leached $(\mathrm{mg})$ in Pasture + Tree treatments, agronomic soils and forest soils in 2007, 2008 and 2009. Different letters indicate significant differences between years within Pasture + Tree treatments (a), agronomic soils (b) and forest soils (c). Vertical lines indicate mean standard error. with Fraxinus excelsior L. and fertilised with similar doses of sewage sludge to our study. However, in the F. excelsior L. experiment the percentage of sand (91.81\%) was higher compared with the soils of the present study. On the other hand, it should be noted that total $\mathrm{Cu}$ leached was reduced over time, possibly due to establishment of pasture and trees. At the beginning of the experiment, trees and pastures were being established, and therefore less efficient at taking up soil nutrients like $\mathrm{Cu}$. Later on, the adequate establishment of pasture and tree probably limited $\mathrm{Cu}$ leaching. Silvopastoral systems are recognised by many authors as a means to reduce the environmental risks associated with the leaching of $\mathrm{N}$ and heavy metals because tree roots can explore a greater soil depth and volume than pasture roots and take up nutrients not employed by the pasture (Nair et al., 2008; Rigueiro-Rodríguez et al., 2008). The positive effect of the establishment of pasture and trees on the reduction of $\mathrm{Cu}$ leaching was also observed in the treeless agronomic soils (Agronomic soils: Pasture) when the weighted mean of the $\mathrm{Cu}$ concentration in the leached water was studied. In the treeless agronomic soils of this study, the pasture production tended to be lower in the pots not fertilised $\left(10.48 \mathrm{Mg} \mathrm{ha}^{-1}\right)$ than when sewage sludge was applied (11.14 $\mathrm{Mg} \mathrm{ha}^{-1}$ ) (Mosquera-Losada et al., 2010a) which probably increased the Cu extractions by pasture in the pots fertilised with sludge and therefore reduced the $\mathrm{Cu}$ leaching through the soil profile. Despite the higher leaching of $\mathrm{Cu}$ at the beginning than at the end of the experiment, the concentration of $\mathrm{Cu}$ in the leached water was always, in all treatments, below the maximum set by the Spanish legislation for drinking water $\left(<2 \mathrm{mg} \mathrm{Cu} \mathrm{l}^{-1}\right)$ (R.D.

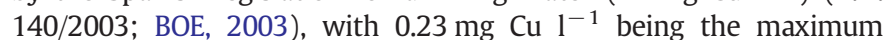
concentration found in this experiment, which is indicative of the low $\mathrm{Cu}$ concentration in the sewage sludge used in this study. Other authors, such as Toribio and Romanyá (2006), also found that the amount of $\mathrm{Cu}$ in the leached water after the addition of sewage sludge was far below the limits of the water quality criteria of the Spanish legislation (R.D. 140/2003; BOE, 2003). These results are highly relevant because sewage 


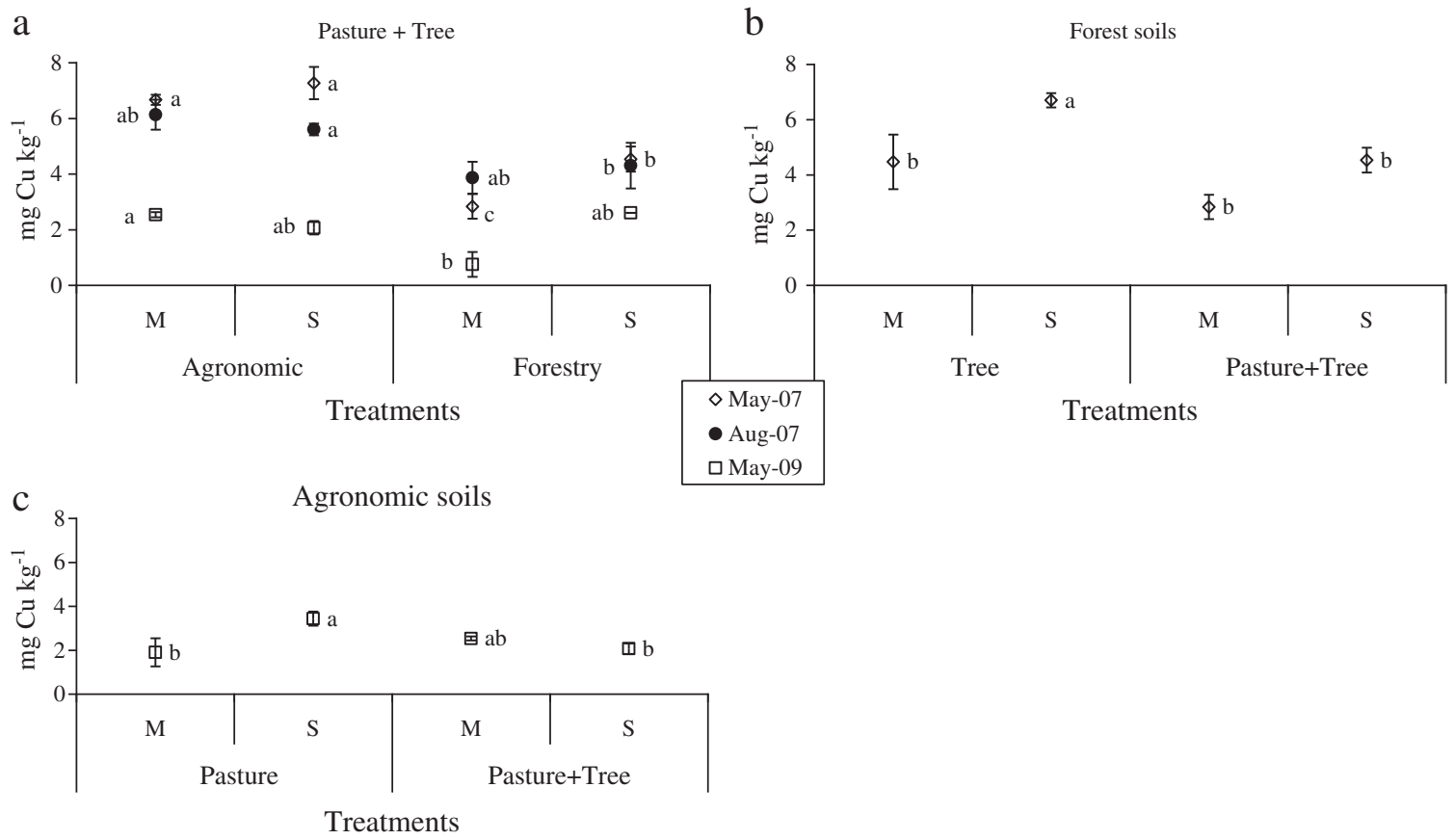

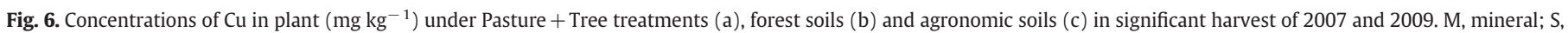

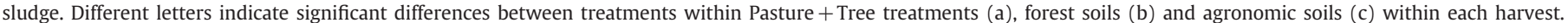
Vertical lines indicate mean standard error.

sludge inputs improve the physical (Griffiths et al., 2005) and chemical (Speir et al., 2004) characteristics of the soil, rather than causing the detrimental environmental effect of $\mathrm{Cu}$ leaching to groundwater, as long as the establishments of pasture and trees are adequate. However, the proportion of $\mathrm{Cu}$ in the sludge must be low, like that used in this study (Karvelas et al., 2003). The improvement of the quality of the sludge through the implementation of techniques reducing the concentration of heavy metals in the residue should be promoted as recommended the European Union in the third draft of the document on bio-wastes (EU, 2000).

On the other hand, in this study, $\mathrm{KCl}$ soil $\mathrm{pH}$ was significantly higher in agronomic than in forest soils. The higher $\mathrm{pH}$ and aluminium levels (data not shown) found in agronomic than in forest soils could be explained by the recent history of liming and fertilisation of agronomic soils, which indicates a higher soil fertilisation in the former. Moreover, when agronomic and forest soils were compared (Pasture + Tree treatments) and within forest soils with sown pasture, it was found that the application of sewage sludge increased the soil $\mathrm{pH}$ more than mineral fertilisation. The improvement of soil $\mathrm{pH}$ caused by the residue applications compared with mineral fertilisation could be due to the inputs of $\mathrm{Ca}, \mathrm{Mg}$ and micronutrients performed with the sludge

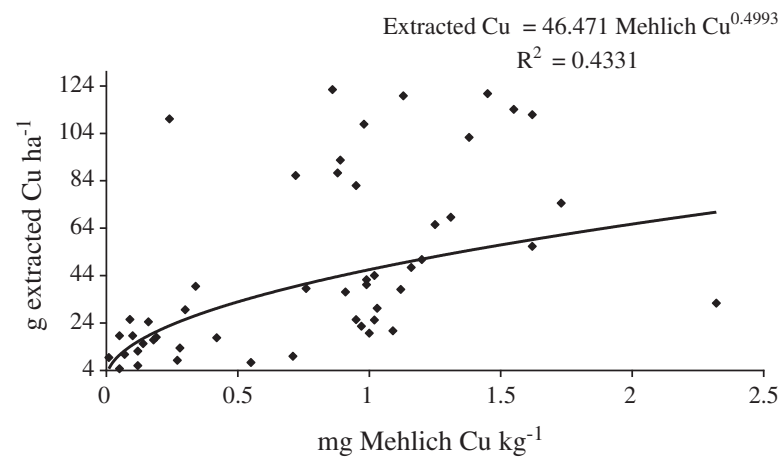

Fig. 7. Relationships between the amount of Cu extracted with Mehlich $3\left(\mathrm{mg} \mathrm{kg}^{-1}\right)$ and the $\mathrm{Cu}$ extracted by the sward $\left(\mathrm{g} \mathrm{kg}^{-1}\right)$. compared with mineral fertiliser as observed in previous studies (Smith, 1996; López-Díaz et al., 2007; Mosquera-Losada et al., 2010b).

The levels of total $\mathrm{Cu}$ in the forest $\left(1.3-5.63 \mathrm{mg} \mathrm{Cu} \mathrm{kg}^{-1}\right)$ and agronomic soils (9.63-14.17 $\mathrm{mg} \mathrm{Cu} \mathrm{kg}^{-1}$ ) found in this experiment can be considered to be low when compared to the usual range for unfertilised soils obtained by several authors, such as Barber (1995) (1-50 $\mathrm{mg} \mathrm{Cu} \mathrm{kg}^{-1}$ ) and Kabata-Pendias and Pendias (2001) (6-60 mg Cu kg-1). Moreover, in all treatments, the concentration of total soil $\mathrm{Cu}$ was always below the maximums set by Spanish regulations for the use of sewage sludge in agriculture for acid soils (50 $\mathrm{mg} \mathrm{kg}^{-1}$ ) (R.D. 1310/1990) (BOE, 1990). This may be explained by the fact that this experiment was located in an area without nearby pollution sources and that both soils have low initial levels of this element compared with the levels found by other authors such as Egiarte et al. (2008) (13.4 mg Cu kg $\left.{ }^{-1}\right)$, Antoniadis et al. (2010) (58.5 $\mathrm{mg} \mathrm{Cu} \mathrm{kg}^{-1}$ ) or Guan et al. (2011) (37.4 $\mathrm{mg} \mathrm{Cu} \mathrm{kg}^{-1}$ ). On the other hand, the values obtained of $\mathrm{Cu}$ Mehlich 3 were similar to the concentrations found by Rigueiro-Rodríguez et al. (2010) in acid soils (0.2-1.8 $\mathrm{mg} \mathrm{Cu} \mathrm{kg}^{-1}$ ) in this region. In this study, the total and Mehlich 3 soil levels of $\mathrm{Cu}$ were lower in forest than in agronomic soils. This result could be explained by the lower $\mathrm{pH}$ in forest than in agronomic soils, which probably restricted the biological activity in the former (Omil et al., 2007; Djukic et al., 2009) and therefore decreased the incorporation and the mineralisation rate of the sewage sludge in forest soils compared with agronomic soils. The negative effect of the soil $\mathrm{pH}$ on biological activity was also observed in forest soils. This explains why in forest soils there were no effect of fertilisation or sowing treatments on the concentration of total and Mehlich 3 soil Cu. Finally, within the agronomic soils, an increment of the concentration of total and Mehlich $3 \mathrm{Cu}$ was found when sewage sludge was used as fertiliser compared with both mineral and no fertilisation treatment. This result was probably due to the higher total $\mathrm{Cu}$ amount applied with the sewage sludge than with the mineral fertiliser (Verloo and Willaert, 1990; MosqueraLosada et al., 2009a). Cu, after $\mathrm{Zn}$, is the most abundant heavy metal in the sewage sludge named by Spanish regulation (R.D. 1310/1990) (BOE, 1990) to consider when applying sewage sludge in agriculture (Mosquera-Losada et al., 2010b). In previous studies, many other 
authors have also shown an increase of $\mathrm{Cu}$ in soil as a result of sewage sludge applications (Mosquera-Losada et al., 2009a; Yuan, 2009; Rigueiro-Rodríguez et al., 2010). Reducing the levels of Cu in the sludge should be done to avoid the increase of this element in soil, as a consequence of sewage sludge inputs. Avoiding plant $\mathrm{Cu}$ uptake could be done through the inputs of lime. However, lime inputs would reduce the soil Cu solubility and Cu plant uptake at short term in soils with a clear acidity tendency, like Galician soils.

The concentrations of $\mathrm{Cu}$ in plant developed in forest $(0.75-$ $6.97 \mathrm{mg} \mathrm{Cu} \mathrm{kg}^{-1}$ ) and agronomic soils (1.6-11.57 $\mathrm{mg} \mathrm{Cu} \mathrm{kg}^{-1}$ ) of this study were slightly below that found in the average plant range (5-20 mg Cu kg-1; Loué, 1988) and the levels of 20 and $100 \mathrm{mg} \mathrm{Cu}$ $\mathrm{kg}^{-1}$ considered excessive or toxic for plants (Smith, 1996; KabataPendias and Pendias, 2001). Moreover, the Cu concentration in plant of forest and agronomic soils were similar to those found by Mosquera-Losada et al. (2009a) (1-9.3 mg Cu Kg${ }^{-1}$ ) and by Mosquera-Losada et al. (2009b) (4.26-6.53 $\left.\mathrm{mg} \mathrm{Cu} \mathrm{Kg}^{-1}\right)$ in silvopastoral systems established in forest and agronomic soils, respectively, and also fertilised with sewage sludge. As observed in this study, the amount of heavy metals removed by plants depends mainly on their availabilities in the soil (Krebs et al., 1998; Stanhope et al., 2000) and on the species (Mosquera-Losada et al., 2001, 2009a; Kidd et al., 2007). In this experiment, $\mathrm{Cu}$ availability and therefore the $\mathrm{Cu}$ concentration in plant was higher in the agronomic soils than in forest soils and when sewage sludge was applied compared with mineral fertilisation in the agronomic soils. Moreover, in the agronomic soils, there is apparently a greater concentration of $\mathrm{Cu}$ in plant of the pots without trees and fertilised with sludge (PS) than in the pots planted with trees and fertilised also with sludge (PST), probably due to the higher availability of this element in the PS treatment than in the PST treatment, but also in part to tree extractions. Regarding the influence of the species on the accumulation of $\mathrm{Cu}$ in the plants, it was found that the concentration of $\mathrm{Cu}$ in plant of the forest soils was lower in the treatments sown with Dactylis glomerata L., Lolium perenne L. and Trifolium repens L. than in the unsown treatments, which have herbaceous species coming from the soil seed bank. This result could be explained by the fact that the sowing increased the proportion of monocotyledons species in the pasture that do not accumulate this element (Mosquera-Losada et al., 2001, 2009a). Previously, authors such as Jarvis (1980) also observed differences in Cu absorption depending on the species; in the study by Jarvis (1980) the concentration of $\mathrm{Cu}$ in white clover was greater than in ryegrass. With regard to animals, the maximum $\mathrm{Cu}$ in forage concentration established by NRC (1980) for bovines (100 mg Cu kg-1), ovines (25 mg Cu kg${ }^{-1}$ ), and equines ( $800 \mathrm{mg} \mathrm{Cu} \mathrm{kg}^{-1}$ ) were never exceeded, which indicated that the pasture in this experiment is adequate for animal consumption. However, $\mathrm{Cu}$ maintenance requirements of goats $\left(7 \mathrm{mg} \mathrm{Cu} \mathrm{kg}{ }^{-1}\right.$; Lamand, 1981), horses (9 mg Cu kg-1; NRC, 1989), bovines (4 mg Cu $\mathrm{kg}^{-1}$; NRC, 2000), and ovines ( $5 \mathrm{mg} \mathrm{Cu} \mathrm{kg}{ }^{-1}$; NRC, 1985) were reached in the agronomic soils but not for bovines and ovines in the forest soils. In these cases, giving $\mathrm{Cu}$ supplements to the animals would be recommended if their nourishment was derived solely from these pastures.

\section{Conclusion}

Inputs of $\mathrm{Cu}$ into the soil from sewage sludge in this experiment, did not cause water quality problems or harmful effects on plants or animals The restricted microbial activity to mineralise the sludge reduced more the availability of $\mathrm{Cu}$ in forest than in agronomic soils, which makes advisable to further evaluate forest soils. Sewage sludge inputs increased the soil $\mathrm{Cu}$ availability and the plant $\mathrm{Cu}$ concentration, mainly when a high proportion of unsown sward species was detected. The use of high quality sewage sludge (with low levels of $\mathrm{Cu}$ ) as fertiliser could improve the global productivity of forest, agronomic and silvopastoral systems without causing $\mathrm{Cu}$ environmental risks.

\section{Acknowledgments}

We are grateful to CICYT and XUNTA for financial assistance and to Escuela Politécnica Superior for their facilities. We also acknowledge José Javier Santiago-Freijanes, Divina Vázquez-Varela, Pablo Fernández Paradela and Teresa Piñeiro-López for help with sample processing in the laboratory and the field. This research was funded in part by the Educational, Science and Technology Ministry (CICYT) and the autonomous regional government of Xunta de Galicia.

\section{References}

Antoniadis V, Tsadilas CD, Samaras V. Trace element availability in a sewage sludgeamended cotton grown Mediterranean soil. Chemosphere 2010;80:1308-13.

Barber SA. Soil nutrient bioavailability. A mechanistic approach. New York, USA: John Wiley and Sons, Inc; 1995.

Baryla A, Laborde C, Montillet JL, Triantaphylides C, Chagvardieff P. Evaluation of lipid peroxidation as a toxicity bioassay for plants exposed to copper. Environ Pollut 2000;109:131-5.

Benavides R, Douglas EG, Osoro K. Silvopastoralism in New Zealand: review of effects of evergreen and deciduous trees on pasture dynamics. Agroforest Syst 2009;76:327-50.

Bhogal A, Nicholson FA, Chambers BJ, Shepherd MA. Effects of past sewage sludge additions on heavy metals availability in light textured soils: implications for crop yields and metal uptakes. Environ Pollut 2003;121:413-23.

BOE (Spanish Official Bulletin). Real Decreto 1310/1990 29 de Octubre de 1990, que regula la utilización de los lodos de depuración (Royal Decree 1310/1990 29th October 1990, that regulates the use of sewage sludge). Madrid, Spain: Ministerio Agricultura, Pesca y Alimentación; 1990http://www.boe.es/boe/dias/1990/11/01/ pdfs/A32339-32340.pdf. Accessed 7 January 2011.

BOE (Spanish Official Bulletin). Real Decreto 140/2003 de Febrero de 2003 por el que se establecen los criterios sanitarios de la calidad del agua de consumo humano. Madrid, Spain: Ministerio Agricultura, Pesca y Alimentación; 2003.

CEM. Microwave digestion applications manual. San Francisco, USA: CED, Matthews, NC; 1994.

Djukic I, Zehetner F, Mentler A, Gerzabek MH. Microbial community composition and activity in different Alpine vegetation zones. Soil Biol Biochem 2009;42:155-61.

Dupraz C, Liagre F. Agroforesterie. Des arbrés et des cultures. Paris, France: France Agricole Editions; 2008

EFMA (European Fertilizer Manufacturers Association). Annual report 2009. Modern agriculture feeds the world and helps protect environment; 2009http://www. efma.org/.. Accessed 15 June 2011.

Egiarte G, Pinto M, Ruíz-Romera E, Camps Arbestain M. Monitoring heavy metal concentrations in leachates from a forest soil subjected to repeated applications of sewage sludge. Environ Pollut 2008;156:840-8.

Egiarte G, Pinto M, Ruíz-Romera E, Camps Arbestain M. Changes in heavy metal concentrations in acid soils under pine stands subjected to repeated applications of biosolids. Soil Sci 2009;174:372-9.

EPA (Environmental Protection Agency). Land application of sewage sludge. A guide for land appliers on the requirements of the federal standards for the use of disposal of sewage sludge, 40 CFR Part 503. Washington, USA: Environment Protection Agency; 1994.

EU (European Union). DOCE n L 181 04/07/1986.Council Directive 86/278/EEC of 12 June 1986 on the protection of the environment and, in particular of the soil, when sewage sludge is used in agriculture. http://eurlex.europa.eu/LexUriServ/ LexUriServ do?uri=CELEX:31986L0278:ES:HTML1986. Accessed 7 January 2011.

EU (European Union). Working document on sludge, 3rd draft [Brussels]; 2000http:// ec.europa.eu/environment/waste/sludge/pdf/sludge_en.pdf. Accessed 05 December 2011.

EU (European Union). Council regulation (EC) n 1698/2005 of Septembre 2005 on support for rural development by the European Agricultural Fund for Rural Development. http://eurlex.europa.eu/LexUriServ/LexUriServ.do?uri=0J:L:2005:277:0001:0040: EN:PDF2005. Accessed 15 March 2011.

Faithfull NT. Methods in agricultural chemical analysis. Wallingford, UK: CABI Publishing; 2002.

Fjällborg B, Dave G. Toxicity of copper in sewage sludge. Environ Int 2003;28:761-9.

Griffiths BS, Hallett PD, Kuan HL, Pitkin Y, Aitken MN. Biological and physical resilience of soil amended with heavy-metal contaminated sewage sludge. Eur J Soil Sci 2005;56:197-205.

Guan TX, He HB, Zhang XD, Bai Z. Cu fractions, mobility and bioavailability in soilwheat system after Cu-enriched livestock manure applications. Chemosphere 2011;82:215-22.

Jarvis SC. The uptake and distribution of copper in perennial ryegrass and white clover grown in flowing solution culture with a controlled supply of copper. J Sci Food Agric 1980;31:870-6.

Karathanasis AD, Johnson DMC, Matocha CJ. Biosolid colloid mediated transport of copper, zinc and lead in waste-amended soils. J Environ Qual 2005;34:1153-64.

Kabata-Pendias A, Pendias H. Trace elements in soils and plants. Florida, USA: CRC Press; 2001.

Karvelas M, Katsoyiannis A, Samara C. Occurrence and fate of heavy metals in the wastewater treatment process. Chemosphere 2003;53:1201-10.

Katsoyiannis A, Samara C. The fate of dissolved organic carbon (DOC) in the wastewater treatment process and its importance in the removal of wastewater contaminants. Environ Sci Pollut Res 2007;14:284-92. 
Kidd PS, Domínguez-Rodríguez MJ, Díez J, Monterroso C. Bioavailability and plant accumulation of heavy metals and phosphorus in agricultural soils amended by longterm application of sewage sludge. Chemosphere 2007;66:1458-67.

Krebs R, Gupta SK, Furrer G, Schulin R. Solubility and plant uptake of metals with and without liming of sludge-amended soil. J Environ Qual 1998;27:19-23.

Lamand M. Metabolis et besoins en oligoelements des chevres. (Metabolism and need of nutrient elements in goats). In: Morand-Fehr P, Bourbouze A, de Simiane M, editors. Proceedings of the International Conference of Nutrition and Feeding Systems. Tours, France: Itovic-Inra publ; 1981. p. 210-7.

López-Díaz ML, Mosquera-Losada MR, Rigueiro-Rodríguez A. Lime, sewage sludge and mineral fertilization in a silvopastoral system develop in very acid soils. Agroforest Syst 2007;70:91-101.

Loué A. Los microelementos en agricultura. (Microelements in agricultura). Madrid, Spain: Mundi-Prensa; 1988.

Martensson A, Torstensson L. Examine of sewage sludge quality. Facts, Soil Plants, 3. Uppsala, Sweden: Institution of microbiology, SLU; 1997.

Mehlich A. Mehlich 3 soil test extractant: a modification of Mehlich 2 extractant. Commun Soil Sci Plan 1985;15(12):1409-16.

Mosquera-Losada MR, López-Díaz ML, Rigueiro-Rodriguez A. Sewage sludge fertilisation of a silvopastoral system with pines in northwestern Spain. Agroforest Syst 2001;53:1-10.

Mosquera-Losada MR, Fernandez-Núñez E, Rigueiro-Rodríguez A. Pasture, tree and soil evolution in silvopastoral systems of Atlantic Europe. Forest Ecol Manage 2006;232:135-45

Mosquera-Losada MR, McAdam JH, Romero-Franco R, Santiago-Freijanes JJ, RigueiroRodríguez A. Definitions and components of agroforestry practices in Europe. In: Rigueiro-Rodríguez A, McAdam J, Mosquera-Losada MR, editors. Advances in Agroforestry Series. Agroforestry in EuropeDordrecht, The Netherlands: Springer; 2008. p. 3-20.

Mosquera-Losada MR, López-Díaz L, Rigueiro-Rodríguez A. Zinc and copper availability in herbage and soil of a Pinus radiata silvopastoral system in Northwest Spain after sewage-sludge and lime application. J Plant Nutr Soil Sci 2009a;172:843-50.

Mosquera-Losada MR, Ferreiro-Domínguez N, Rigueiro-Rodríguez A, Fernández-Núñez E. Fertiliser type effect on copper cycling in a Fraxinus excelsior L. silvopastoral system. Grassland Science in Europe, 14. ; 2009b. p. 185-8.

Mosquera-Losada MR, Ferreiro-Domínguez N, Rigueiro-Rodríguez A. Fertilization in pastoral and Pinus radiata D. Don silvopastoral systems developed in forest and agronomic soils of Northwest Spain. Agric Ecosyst Environ 2010a;139:618-28.

Mosquera-Losada MR, Muñoz-Ferreiro N, Rigueiro-Rodríguez A. Agronomic characterization of different types of sewage sludge: policy implications. Waste Manage 2010b;30:492-503.

Nair PKR, Gordon AM, Mosquera-Losada MR. Agroforestry. In: Jorgensen SE, Fath BD, editors. Ecological Engineering, Encyclopedia of Ecology. Oxford, UK: Elsevier; 2008. p. 101-10.

Ngole VM. Response of copper, lead and zinc mobility and bioavailability to sludge application on different soils. Pol J Soil Sci 2007;40:125-38.

Nillsson SI. Soil acidification. In: Benbi DK, Nieder R, editors. Handbook of processes and modelling in the soil-plant system. London, UK: Haworth Press; 2004. p. 177-99.

NRC (National Research Council). Mineral Tolerance of Domestic Animals. Washington, USA: National Academic Press; 1980.

NRC (National Research Council). Nutrient Requirements of Sheep. Washington, USA: National Academic Press; 1985.

NRC (National Research Council). Nutrient Requirements of Horses. Washington, USA: National Academic Press; 1989.
NRC (National Research Council). Nutrient requirements of beef cattle. Washington, USA: National Academic Press; 2000.

Omil B, Mosquera-Losada MR, Merino A. Responses of a non-N-limited forest plantation to the application of alkaline-stabilized dewatered dairy factory sludge. J Environ Qual 2007;36:1765-74.

Peri PL, Lucas RJ, Moot DJ. Dry matter production, morphology and nutritive value of Dactylis glomerata growing under different light regimes. Agroforest Syst 2007;70:63-79.

Rigueiro-Rodríguez A, McAdam JH, Mosquera-Losada MR. Agroforestry systems in Europe: productive, ecological and social perspectives. In: Rigueiro-Rodríguez A, McAdam JH, Mosquera-Losada MR, editors. Advances in Agroforestry Series. Agroforestry in EuropeDordrecht, The Netherlands: Springer; 2008. p. 43-66.

Rigueiro-Rodríguez A, Ferreiro-Domínguez N, Mosquera-Losada MR. The effects of fertilization with anaerobic, composted and pelletized sewage sludge on soil, tree growth, pasture production and biodiversity in a silvopastoral system under ash (Fraxinus excelsior L.). Grass Forage Sci 2010;65:248-59.

Sánchez-Rodríguez F, Lopez C, Rodríguez-Soalleiro R, Español E, Merino A. Influence of edaphic factors and tree nutritive status on the productivity of Pinus radiata D. Don plantations in Northwestern Spain. Forest Ecol Manage 2002;171:181-9.

SAS. SAS/Stat User`s Guide: Statistics. Cary, NC, USA: SAS Institute Inc; 2001.

Sigua GC, Adjei M, Rechcigl J. Cumulative and residual effects of repeated sewage sludge applications: forage productivity and soil quality implications in south Florida, USA. Environ Sci Pollut Res 2005;12:80-8.

Singh KP, Mohan D, Sinha S, Dalwani R. Impact assessment of treated/untreated wastewater toxicants discharged by sewage treatment plants on health, agricultural, and environmental quality in the wastewater disposal area. Chemosphere 2004;55: 227-55.

Smith SR. Agricultural recycling of sewage sludge and the environment. Wallingford, UK: CAB International; 1996.

Smith SR. A critical review of the bioavailability and impacts of heavy metals in municipal solid waste composts compared to sewage sludge. Environ Int 2009;35: $142-56$.

Speir TW, Horswell J, van Schaik AP, McLaren RG, Fietje G. Composted biosolids enhance fertility of a sandy loam soil under dairy pasture. Biol Fertil Soils 2004;40: 349-58.

Stanhope KG, Young SD, Hutchinson JJ, Kamath R. Use of isotopic dilution techniques to assess the mobilization of nonlabile $\mathrm{Cd}$ by chelating agents in phytoremediation. Environ Sci Technol 2000;34:4123-7.

Toribio M, Romanyá J. Leaching of heavy metals ( $\mathrm{Cu}, \mathrm{Ni}$ and $\mathrm{Zn}$ ) and organic matter after sewage sludge application to Mediterranean forest soils. Sci Total Environ 2006;363:11-21.

VARIAN. Analytical methods. Mulgrave, Australia: VARIAN; 1989.

Verloo M, Willaert G. Direct and indirect effects of fertiliser practices on heavy metals in plants and soils. In: Merckx R, Verecken H, Vlassak K, editors. Fertiliser and the Environment. Belgium: Leuven University Press; 1990. p. 78-87.

Whitehead DC. Grassland Nitrogen. Wallingford, UK: CAB International; 1995.

Yuan G. Copper, zinc, and nickel in soil solution affected by biosolids amendment and soil management. Aust J Soil Res 2009;47:305-10.

Zas R, Alonso M. Understory vegetation as indicators of soil characteristics in northwest Spain. For Ecol Manage 2002;171:101-11.

Zubillaga MS, Bressan E, Lavado RS. Heavy metal mobility in polluted soils: effect of different treatments. Am J Environ Sci 2008;4:620-4. 